\title{
O NOVO E O ORIGINAL
}

\section{THE NEW AND THE ORIGINAL}

\author{
Achille Picchi \\ Universidade Estadual Paulista \\ achillepicchi@gmail.com
}

Trata-se aqui de pensar, sucinta, mas abertamente, sobre a composição musical na contemporaneidade. Para tanto esta reflexão vai ser dividida, em maior ou menor grau, em tres momentos, isto é, como se situa a contemporaneidade, como a composição musical se encaixa na discussão anterior e como o compositor se situa nesse contexto.

\section{Da contemporaneidade e onde se diz do novo e do original}

Se tivermos em mente que História é constructo humano, sem dúvida embasada nos discursos resultantes dos recortes feitos pelo historiador, poderemos perceber que contemporâneo não só é recurso do mesmo jaez para compreensão social, mas, principalmente, para inserção ideologico-cultural das manifestações, em especial as artísticas. Em principio, a contemporaneidade seria o "tudo agora", o entorno observacional enquanto vivenciado. De alguma forma ficamos conscientes do passar temporal da História e de sua natureza construida que nos leva da experiência ao conhecimento.

Na tentativa de compreensão de nossa contemporaneidade,

\footnotetext{
- Palestra apresentada no dia 18 de outubro de 2014, no Departamento de Música da Faculdade de Filosofia, Ciências e Letras de Ribeirão Preto da Universidade de São Paulo, dentro da programação do VI Encontro de Musicologia. Disponível em https:// youtu.be/XvyNfvOXOCo?list=UU7kMPRd6yA9Pulnjl6voHXA (acessado em 10.11.2015).
} 
coletiva ou individual, não conseguimos, porém, observação com afastamento e isenção suficientes, como se faria de um tempo aparentemente estático, o passado remoto. No presente mediado que vivemos não há locais seguros aonde se possa realizar essa observação, nem a Ciência, nem a Religião, sequer a História como disciplina. Menos ainda a Arte. Como racionais tentamos a compreensão analítica e essa não é possivel em função das estruturas que empregamos para as análises sendo, como são, pertinentes ao tempo corrente.

Chegando, porém, ao contemporâneo na música, ve-se que ele se posta após o modernismo e assim adquire, digamos, um status de movimento, cuja diferença, interpenetrada pela cultura de massa muita vez, e pela crítica em muitos momentos, pelos vieses político-ideológicos em grande parte, e pelo repertoriar da cultura enquanto diferença de um modo geral, adveio das vanguardas como um subsídio de estabelecimento e estamentação.

Considerado como processo e representação de época, Teixeira Coelho entende que as relações pessoas-universo em que vivem - ou consciência-da-época e artista-criador - definem melhor o modernismo que simplesmente ruptura com o passado, talvez chamado de moderno. E continua: "[s]endo uma representação, o modernismo é mais uma fabricação do que uma ação" (COELHO, 201 1, p.32). Mais adiante, abre o caminho para se pensar o pósmoderno: "[s]e o modernismo é fabricação, a ação é o moderno? Não, ação é modernidade". A ação é toda das vanguardas; a ação da subjetividade contra o estilo único, a afirmação do artista mais do que da arte a que se filia, a ligação psicopatológica com a vida social da arte e do artista em conjunto, a fixação na linguagem. A modernidade enquanto ação, será sempre quebra, mas também invenção.

Essas vanguardas processam duas vertentes generalizadas para entronização dos tempos de ação: o novo e o original.

Está no Eclesiastes, 1-9, 10, perfeitamente enunciado: "O que 
foi, assim como era, será; o que aconteceu, assim como acontecera, acontecerá; não há nada de novo sob o sol".

A afirmação do Eclesiastes nos leva aos limites de um entendimento que, na época de sua elocução e principalmente escrita, defronta-nos como regramento: não há de fato a possibilidade do novo sendo o Homem um decaído do Paraíso Celeste. É natural, portanto, que só Deus, como a entidade suprema, incognoscivel, onisciente e constantemente atemporal, pudesse - ou só tivesse a possibilidade de - transformar a potência eterna em ato, dominando assim o novo em toda sua plenitude. Ao Homem cabe - e sempre caberá - o original, a transformação, a continuidade a partir do novo único, a partir da origem, isto é, da criação divina.

Como isto será possivel? Desde que a criação seja, como é, a única viabilidade do novo enquanto novo, pois sua anterioridade não existia até sua instauração efetiva pelo ato divino; então, a partir deste, nada mais não terá anterioridade bastante e suficiente para criar o realmente novo, nada mais de novo haverá "sob o sol", ou seja, na Terra. Exceto no Céu.

Partindo para o campo ontológico, se relevarmos o fato que, aqui, criação está para o processo e este processo provem do nada já que afirmado no vazio do divino anterior, segue-se que o novo teria, factualmente, uma origem única, essa origem que formaria todo o original posterior e que foi delegado ao Homem, visto que sua capacidade de soprar no barro, digamos assim, não the foi dada. Portanto, tecnicamente o Homem cria a partir da origem, ou seja, será sempre original em sua criação - a arte. Por isso renovação na criação e vanguarda como ponta de lança dessa renovação serão sempre buscas, em todos os tempos, da Humanidade, não tanto para romper com o passado ou renega-lo, mas dialogar com ele.

O continuo movimento de cambiamento no que se possa chamar estilistica, nas técnicas, nas incorporações vivenciais $e$, até mesmo, 
revivenciais de um "passado" estilistica e tecnicamente redimensionados vem trazendo, no dizer de Meyer, "algum calor, uma considerável fumaça, mas muito pouca luz" ao contemporâneo (MEYER, 1988, p.88). Ou, parodiando Agamben, filósofo italiano, a obscuridade do presente sempre busca na luz da modernidade passada a sua atualidade e atualização (AGAMBEN, 2008). O original.

São essas duas questões, do novo e do original - duas facetas que se aparentam e mesmo muitas vezes têm sido tomadas como sinônimos (ou quase), como se verá em seguida - que se apresentam (e, me parece, sempre se apresentaram) à criação musical contemporânea.

quantum de dilema ou de indiferença entre elas repousa mais sobre o histórico-ideológico que propriamente artístico ou composicional.

O que seria, então, novo (e, daí, novidade) e original (e originalidade) na composição musical - principalmente na contemporaneidade?

Nos dicionários encontramos dilemas em forma de explicativas. Por exemplo, no dicionário Michaelis está: novo - o que existe há pouco tempo, o nascente, o incipiente, o original. Já no supermercado das palavras, o dicionário Aurélio, consta: novo - que existe há pouco, moderno, que começa.

Se buscarmos original nesses dois dicionários de referência, obteremos no Michaelis: original - relativo à origem, que tem caráter próprio não copiado ou imitado. No Aurélio: original - relativo à origem, primitivo, inventado (dizendo que este termo seria o não copiado ou imitado).

Como talvez se possa ver, etimologicamente entre novo e original há a, digamos, diferença de início, isto é: do novo nada existia 
antes; do original é do antes, da origem, do inventado que existe algo. Mas essa fundamentação não está lá contemplada. Entretanto, para a criação, espaço humano extenso e até certo ponto delimitador do Humano, entre o novo e o original, como já aventado antes, estende-se o passado.

Como construção, para a criação o novo denega e o original utiliza. De certa forma a diferença (se diferença se puder chamar) entre o novo e o original na criação musical funda-se na ruptura, quase sempre via experimentação e na manutenção, em geral via contraposição às rupturas e apreço à tradição como caminho de progresso. É, como já mencionado, construção e por isso permeado de relações socioculturais, sociopoliticas. No nosso caso, sociomusicais inevitavelmente, mesmo que não se possa percebe-lo em primeira instância.

Pode-se dizer então que a novidade é uma instauração e a originalidade um processamento do já instaurado, mas transformado. Liga-se, normalmente, às vanguardas a idéia do novo, mas nem sempre a do original. Isto é, algo que tende a não mais seguir o já estabelecido e nem mesmo reformar ou transformar o estabelecido é o constituinte da matéria do novo.

Observa-se, ao longo do tecido histórico-social que, numa visão ampla isto sempre se deu por dois aspectos: revolução humana e revolução da linguagem, nem sempre separadamente, mas às vezes; e nem sempre os dois em conjunto, mas também.

No caso da arte da composição musical, mais ocasiões em que não, se fez por revoluções da linguagem, tomada aqui, é claro, linguagem num sentido genérico não literal, como tessitura de sentidos.

Visto do alto e largamente, teremos, então, a idéia de novidade como radicalização (como o stil nuovo da renascença ao barroco, ou a expansão do campo tonal através do cromatismo a partir da segunda metade do século XIX, O wagnerianismo, o modernismo e a 
busca de novos materiais do começo do século XX, as experimentações sonoras, os ruídos, a eletroacústica, etc.); e a originalidade como transfiguração da tradição por distensão do paradigma do que seja música (a Querelle des Buffons do século XVIII, a questão Brahms-Wagner e Hanslick e a música pura, o nacionalismo e a polêmica do povo, o zhdanovismo e servidão da música ao Estado, o neoclassicismo, etc.). Lembro um artigo, escrito para o extinto suplemento MAIS! da Folha de São Paulo, de 2004, por Rogério Cezar de Cerqueira Leite. Embora um físico conceituado, professor emérito da UNICAMP, não se the pode atribuir tanta autoridade assim no que tange à música - ou à crítica musical, por falar nisso -, muito embora seu ego superatômico se considere enormemente capaz. Porém, é preciso conceder-lhe argúcia argumentativa.

No artigo que menciono, "Monteverdi, o Maquiavel da música", Cerqueira Leite trata de defender a idéia de que na História da Música "nõo há revoluções, apenas transformações. Eis porque historiadores e comentaristas tanto se contradizem" (LEITE, 2004, p.3). Coloca, por assim dizer, o dedo na ferida de sempre, ou seja, embora tudo se renove, na verdade nada há de novo. Entretanto, argumenta ele, existem pontos históricos nodais de exceção a confrontar tal idéia - e um deles, importantíssimo, é Cláudio Monteverdi. Este teria escapado à tese graças ao que o crítico denominou de "maquiavélico estratagema", um simples ardil que fez confundir seus detratores, inimigos, tais como o crítico Artusi, por exemplo, um dos mais importantes de sua época.

Monteverdi se defende com uma "declaração inequivoca de que um novo estilo estava sendo inaugurado e que, portanto, não havia obrigação nenhuma de novas composições obedecerem às regras do "stile antico'" (LEITE, 2004, p.3).

Já ouvimos falar e até lemos muito isto desde a modernidade até a pós-modernidade contemporânea. A alegação é a falta de afastamento histórico ou inauguração quase sempre absoluta de processos, técnicas, estilos, atitudes composicionais, interpenetrabilidade 
de linguagens, etc., o que parece justo e adequado. Mas analistas, músicos, comentadores e críticos (em geral propagadores, quando não formadores, de opinião) da nova música atestam sua validade por não haver mais "obrigação nenhuma" com estéticas, sócio-estéticas, técnicas, estilos, correntes, ideologias, etc., sendo recente expressão. Ou seja, a não-compreensão do novo, algo intrínseco a todo novo, não o invalida por novo, excluindo-o ao tradicional, mas por recente.

Parece, entretanto, claro que por muitas vezes aqueles críticos, comentadores, analistas, músicos em geral não realizam e promovem essa validação somente pela coisa em si, isto é, a obra (que eu não me atreveria a pensar como ser-aí para sua colocação no universo da criação musical), mas, especialmente, por sua evocação difusiva $e$, ainda mais, pela posição ocupada ou não por seu autor-criador.

Walter Wiora observa que, em geral, inovadores tendem a considerar o novo (ou suas novidades) não como um caminho entre outros, mas como "o único caminho que corresponde ao estágio presente de composição e da sociedade em processo" (UIORA, 1965, p.151).

Wiora parece lidar com o novo de forma a questionar a denegação (ou até, talvez, destruição) do passado enquanto conhecimento para o progresso corrente e relega-lo á História, como fato ou como conhecimento para acesso ou simplesmente exemplo de não utilização sem, contudo, considerar sua direção constante ao futuro. E ressalta a "revolução" permanente e cooperativa entre compositores e atores da criação musical que dessa forma acreditam na busca do novo (UIORA, 1965, pp. 175-176):

Essa rápida sucessão de inovações foi baseada principalmente no esforço intensivo de criar 'o novo' dai em diante, numa inaudita persistência na consecução do objetivo escolhido como um dever capital e um padrão capital de valores.

Não se pode deixar de notar que a vanguarda, enquanto de- 
tentora do novo como ponta-de-lança que efetivamente é, já nasce com a morte anunciada. Isto é, uma vez entronizada, quando acontece, deixa de ser novo para ser original, tal qual o próprio Wiora observa: "[...] depois do 'término da Nova Música de Ontem' será a única música que conta" (UIORA, 1965, p.177). Será o apreciado como passado recente da música do tempo presente. Do mesmo modo como a História se refere pela significação do que o fato histórico tem como consequência, a vanguarda cria a cunha eventual que faz da consequência o perene futuro.

O que aparenta acontecer na composição a partir do modernismo até a atualidade diz respeito a, pelo menos, dois aspectos, muito mais de natureza antropológica que musical.

Primeiro, a invasão estético-formal do gosto do compositor, de visada pós-moderna, isto é, já crise da modernidade, como refere Pondé: "A afirmação de que a modernidade está em crise é já senso comum, temos até mesmo uma grife para essa crise: "pós-modernidade"' (PONDÉ, 2010, p.51). O gosto é um destacado marco do presente composicional, ou seja, da atualização do moderno; é uma constante e cada vez mais aprofundada centralização no material de realização e menos impacto na ação exterior de ambos.

Depois, e em estreita ligação com essa invasão estético-formal do gosto, há a por vezes desesperada tentativa de escapar a todo custo da tradição, algo que lembre a tradição, a que a ela se remeta ou se reporte.

Shostakovitch, num pequeno livro com o sugestivo titulo de " $\bigcirc$ Poder da Música", diz:

Transformou-se de algum modo num hábito entre nós de opor inovação à tradição. Os compositores com frequência são divididos entre 'inovadores' e 'tradicionalistas'[...] Daí é essencial distinguir entre tradições mortas e vivas e entre inovações genuínas e espúrias (SHOSTAKOVITCH, 
1968, p. 26).

Se Shostakovitch refere-se aos inovadores embutindo a experimentação, embora não a explicite, mais adiante coloca que toda forma de inovação funda-se na melhor das tradições. Relembro, então, um artigo de Moacyr Scliar, escrito para o suplemento MAIS!, da Folha de São Paulo, em 2002, muito expressivo: "experimentalismo é uma faca de dois gumes [...] Não basta ser experimental, é preciso ser muito bom no que se está experimentando" (SCLIAR, 2002, p. 10).

A questão da tradição e sua relação com a composição contemporânea é grande demais para ser tratada aqui devidamente. Entretanto vale ser ressaltada em alguns pequenos pontos.

De alguma maneira há uma recorrência ao referencial anterior no processo modernista. E esse recorrer, agindo por contiguidade ou por denegação específica é marco pós-moderno contemporâneo igualmente. Uma das características que a isso diz respeito seria o caráter de ruptura moderno/pós-moderno que é, como diria Hobsbawm, a reação a repetições e cristalizações que se tornem "costume" (HOBSBAUM, 1997). Assim a ação pós-moderna pauta a "invenção das tradições", frutos posteriores da vanguarda - apenas para, em movimento contínuo, reagir a elas em seu caminho inevitável para a invariabilidade, imutabilidade, inflexibilidade. Fato que talvez explique porque Schoenberg, em 1942, numa conferência famosa deu por encerrado o dodecafonismo.

Diz o compositor Ellioł Carter que a tradição "não somente é um meio de continuar perseverando num caminho, mas também um meio de desviar-se dele" (CARTER, 1992, p.42). O que nos remete de volta a Shostakovitch e as tradições mortas e vivas e inovações espúrias e genuínas. Ou seja, a inovação (ou invenção, como queria o poeta Ezra Pound, 2006), a novidade como desvio; e o original (ou a maestria, como diria Pound), como transformação ou transfiguração da tradição. 
A designação "música nova" ou "nova música" foi introduzida, nos últimos tempos, na década de 1920, especialmente para descrever aproximadamente novos sons, relativamente ao uso, no chamado modernismo (o tratamento, na linguagem musical, "igualitário" da dissonância, por exemplo, ou a incorporação dos ruídos); como também novas tendências (caminhos especialmente técnicos ou o abandono imediato ou brusco de "procedimentos técnicos antigos"); novos instrumentais, novas atitudes, novos gestos sonoros e físico-sonoros, novos usos para instrumentos tradicionais, etc.

É interessante notar que a palavra "nova" foi especificamente aplicada em, pelo menos, tres grandes momentos da História da Música Ocidental, com aproximadamente 300 anos de diferença entre eles; e em cada um foi usada para descrever mudanças súbitas e importantes (ou consideradas importantes para o momento histórico) que estavam presentes no estilo musical. Assim foi no ARS NOVA (A música nova ou a arte nova), c. 1300; no NUOVE MUSICHE (As novas músicas, designativo generalizado para a mudança da época emprestado de uma coletânea de Caccini), c.l600; e a MÚSICA NOVA (ou Neue Musik, especialmente), c. 1900.

Há uma diluição cada vez maior de interesses e profundidades musicais contida na expressão composicional, devida especialmente à velocidade de acesso à informação e nenhum tempo de digestão dela na contemporaneidade.

O fato de que tudo - ou quase tudo - pode ser conhecido praticamente ao mesmo tempo e praticamente de forma integral lembra o dito da especialização: diz-se que quanto mais se especializar em conhecer cada vez mais sobre alguma coisa, chegará o dia que se conhecerá tudo sobre coisa alguma.

Se antes os problemas ou dilemas do compositor comportavam apenas a música e a música ruim, visto que o universo onde se movia a composição era suficientemente referencial, hoje o compositor escorre- 
ga sobre um plano entre a música, a também-música e a não-música. indiscriminado ocorrente nestes tempos e sempre mais confuso em suas fronteiras refaz o percurso do valor para a extensão do indivíduo e não do corpus composicional.

Isso quer, de certa forma, dizer que uma valoração técnico-etica da composição do século XXI, especialmente, moveu-se em grande medida para o círculo de validação interpares ou intramuros pseudo - estilística. Dizer que a música contemporânea acha-se num beco sem saída é uma apostasia tão grande hoje como o deverá ter sido sempre, de maneira que sua importância como assertiva só poderá ser a histórico-diferencial. No entanto, se antes essa assertiva representava, de alguma forma, o usual embate entre o velho e o novo, no sentido representativo do conservadorismo e do progressismo, do ultrapassado e o moderno enquanto posicionamento ideológico, já hoje os termos dessa dialética, com os quais sempre lidamos, não possuem contornos definidos ou sequer apontam possibilidades de tomada de posição que não sejam partidarismos, pura e simplesmente. Ou, quiçá, preconceitos.

Já não há mais o "bem" e o "mal", a supremacia a ser alcançada e o mal a ser combatido, o erro a ser erradicado, anjos e a exorcização dos demônios. Tudo é, quase sempre, tabula rasa.

A composição não existe vinda do nada. Os compositores, enquanto compositores, afinal, têm uma função social e uma responsabilidade para e com a sociedade no qual estão imersos e de onde, certamente provêm, como criadores e como realizadores da obra. Se ela, a função social, é ou não definida nos tempos correntes, resta a opção aos próprios compositores. A definição dos compositores, ao contrário do totalitarismo da indústria cultural de massas atual, é proporcional à sua competência. Que, no entanto, posmodernamente, pode ser camuflada.

Em suma, os bons compositores são aqueles que conseguem 
realizar e manter uma eficiência para sua linguagem. E, em termos de criação, sobre a composição pode-se aplicar o dito de Ezra Pound sobre a literatura, com a necessária adaptação: a grande composição musical (ou talvez a grande Música) é "simplesmente linguagem carregada de significado até o máximo grau possível" (POUND, 2006, p.40). Numa passagem célebre o poeta e crítico classifica a criação em seis niveis: os inventores, os mestres, os diluidores, os bons escritores (bons compositores) sem qualidades salientes, os beletristas e os lançadores de moda.

Pound interpenetra assim criadores e criação num efeito extremamente modernista, de um ponto de vista das relações (pessoas universo, artista e consciência de época). E pós-moderno enquanto tomado pelo gosto como viés criativo.

Das seis classificações, adaptam-se importantemente bem as três primeiras à composição musical.

Diz ele que os inventores são os que descobriram um novo processo ou os que nos dão o primeiro exemplo deste. De certa forma posiciona aí o novo; mas sob o quesito da inovação ou do inusitado - então, novidade. Em resumo, o processo se pode tomar por técnico como adiante se discutirá mais extensivamente.

Depois coloca os mestres, os que combinaram certo número de tais processos e os usaram tão bem ou melhor que seus inventores. Podemos claramente situar as idéias da vanguarda do início do século XX aí, talvez até mesmo num exemplo expressivo: Schoenberg, pater scholas, com o dodecafonismo, inventor; e Berg, Webern, discipulos (especialmente este último), mestres.

Então vêm os diluidores, os que vieram depois dos dois primeiros tipos e, não sendo tão capazes quanto eles, de algum modo simplificam e "diluem" a invenção e sua aplicação magistral quase-ortodoxa. 
Onde novo e original aplicam-se categoricamente nesse caminho pertence mais aos diluidores que aos inventores e mestres, na contemporaneidade. A gradual possibilidade de não mais necessitar inventar, não existir mais a influência enquanto tendência estilística, daí a maestria seguindo a invenção, a individuação (pondo-se fenomenologicamente o termo, ou mesmo de modo psicanalitico) mais acirrada e o inevitável desmembramento do sujeito artístico pós- 1989 possibilitam a essa classificação, os diluidores, a ocuparem um senso de agregação de valor ao que, talvez, antes fosse o desconcerto composicional. Além disso, podem proporcionar, em alguns casos, a emergência dos outros três tipos poundianos: os bons compositores sem qualidades salientes (como ele diz, homens que tiveram a sorte de nascer numa época que aparentemente tudo já é conhecido sob o aspecto de como é feito ou como possa ser feito), que podem realizar o "passado" como ele próprio, num pretenso revisionismo pós-moderno.

Ou os beletristas, que não inventam nada, não seguem ninguém, não podem ser considerados bons compositores estritamente falando, mas, no entanto, dominam um ínfimo, mas eficiente discurso composicional o qual, segundo conceitos mais ou menos globalizados de posicionamento socioartístico demagogicamente democrático do contemporâneo periférico, thes permite vida e aparência.

E, por fim, os lançadores de moda que, pela sua eloquência vocabular substantiva Pound sequer comenta. E aqui se vai fazer 0 mesmo.

\section{Os avatares da composição contemporânea}

Um avatar, tomado aqui no sentido de transformação ou metamorfose, ronda a composição mais que qualquer outro: a técnica. E este, entranhado no produto final e podendo ser desentranhado via análise, ou outro processo decupatório estrutural de cognição de dentro da efemeridade sonora a que se costumou designar por música, 
carreia peso e responsabilidade. Agrega valor e validação. Sobrevivência.

Adorno, num longo e conhecido ensaio, referindo-se à técnica de Mahler, diz: "[f]rente à plenitude musical, a preocupação pela realização se faz concreta no postulado da clareza em todas as dimensões" (ADORNO, 1963, p.138).

A idéia da técnica composicional, como a habilidade de reunir insight, estruturação organizacional, sentido e realização final contempla a ontologia musical e, nela, se faz passado e presente, tradição e ruptura, conservadorismo e vanguarda. Como diria Adorno, na composição só conta o realizado.

Stravinsky afirma peremptoriamente que a técnica "não é uma ciência que se possa ensinar, nem é aprendizagem, nem erudição, nem sequer conhecimento de como fazer alguma coisa. É criação e, como tal, é constantemente nova" (STRAVINSKY \& CRAFT, 2010, p.19). Isto coloca o problema fulcral do modernismo e do pós-modernismo para a composição contemporânea: a fusão de feitura e expressividade como totalidade da Obra. Essa é uma consciência comum à maioria dos compositores contemporâneos, embora o juízo exarado pelo grande compositor de Sacre du Printemps não seja absolutamente consenso.

Camargo Guarnieri costumava dizer que ninguém era obrigado a gostar da música que ele compunha. Entretanto, ninguém poderia afirmar jamais que ela fosse mal feita.

Essa afirmação (que nos foi feita pessoalmente mais de uma vez enquanto aluno), embora eivada de simplicidade, demonstra um orgutho de conquista pessoal do compositor: o domínio técnico. E igualmente coloca uma questão, já antiga: quanto do aparato técnico, dominado e investido numa obra pelo criador, faz dessa obra sua expressão de qualidade ou falta de qualidade?

Há, inclusive, outras questões adstritas e/ou subjacentes que 
podem ser pensadas, quando a referência é a técnica criativa muito especialmente no caso contemporâneo de totalização à obra, tais como: uma obra cuja técnica de realização é mais aparente que outra deixa de ter interesse expressivo? Ou: a descoberta da técnica de criação através, por exemplo, da análise musical, fará qualquer diferença quanto a algum juízo de valor de uma obra?

A relação que um compositor, digno desse nome, tem com a técnica é algo de muito sério, realmente. Por vezes, visceral.

Um fato que se dá, muita vez, quando se emite juízo de valor sobre uma obra musical é a percepção da maestria técnica do compositor. Casos há em que isto se constitui num divisor de águas entre - que se poderia chamar "bom" compositor e compositor "mediocre" - como talvez gostasse o grande Guarnieri de dividir o mundo composicional. Isto é, evidentemente como tudo que o ser humano percebe no mundo, uma opinião mediada, embora possa ser circunstanciada.

Voltando a Stravinsky: "[...] para mim o compositor original ainda é sua própria e única técnica. Se ouço falar no 'domínio técnico' de um compositor, fico sempre interessado no próprio compositor" (idem, ibidem). Saber se o compositor é "bom" porque tem maestria técnica, implica saber o que seja técnica e a maestria que ele emprega. Implica, inclusive, no reconhecimento de ambas as coisas.

Ao se realizar uma reflexão sobre a técnica e a criação musical, impõe-se desde logo um par de idéias que sempre estiveram em vigência quando se trata de aplicar julgamento de valor, análise ou mesmo contemplação de uma obra musical: o artesanato e a realização artística da obra. Por essa óptica colocar-se-ia, talvez taxonomicamente, a técnica na manipulação dos materiais (artesanato) e a realização artística na originalidade final dessa manipulação/organização.

Entretanto, como sempre acontece, classificações, taxonomias, enquadramentos são tão escorregadios quanto seus contrários, es- 
pecialmente quando materiais manipulados e realização artística se confundem ou mesmo se fundem, como na contemporaneidade.

Costaria de examinar, aqui, apenas duas concepções de técnica para realizar a obra, de dois autores - Theodor Adorno e Mário de Andrade - que se debruçaram extensivamente sobre o assunto, para que possamos, em princípio, alocar a questão cuja pertinência e abrangência transcendem a este espaço e tempo.

Como bem se sabe - e Adorno reitera logo de início ao discutir o problema - a palavra técnica provem do grego TEx $v \eta$ (Techné), cujo significado se refere tanto ao mecânico como à habilidade de realização, ou seja, o estro, o talento. Segundo Adorno, também se refere à realização externa de um interior, ou seja, "o conceito de técnica compreende tudo o que se refere à realização desse interior" (ADORNO, 2006, p.233). Assim, Adorno logo enuncia a indissociabilidade da técnica do todo da criação musical, quando refere: "a totalidade dos recursos musicais é a técnica musical” (idem, ibidem).

De certa maneira, logo Mário de Andrade enuncia o mesmo quando diz que "nos processos de movimentar o material, a arte se confunde quase inteiramente com o artesanato" (ANDRADE, 1938, p. 1 l). Embora já use o termo artesanato, no entanto pode-se ver o ponto comum entre os dois autores no que se refere à indissociabilidade técnica do todo da criação, quando Mário de Andrade afirma que "se perscrutarmos a existência de qualquer grande pintor, escultor, desenhista ou músico, encontramos sempre, por detrás do artista, o artesão" (idem, ibidem).

Para Adorno a criação musical deve ser tratada como criação de sentido, inferido do processo de organizar e da ideia mesma: "[...] a obra de arte se converte em contexto de sentido em virtude de sua organização técnica, não há nada nela que não se legitime necessariamente como técnico" (ADORNO, 2006, p.233). 
Considera, assim, a discussão sobre a técnica como alheia à arte e a indissolubilidade do todo (técnica-obra) se pronuncia idêntico e não-idêntico, já que uns geram-se reciprocamente e outros mostram que a obra sem conteúdo não teria sentido e sem exterior nem seria obra.

Quando diz que de nenhum modo "o exterior é meramente determinado pelo interior", Adorno, contemporâneo das revoluções musicais do século XX, se contrapõe ao não formalizado, ao não paralínguistico no contexto da construção musical enquanto procedimento técnico composicional. Este deverá, de modo explícito ou implícito, estar realizado e ser passivel de ser conhecido. Progride através dos meios de realização, de fora para dentro, mas isto nunca impediu o espírito de constantemente domina-los e concebê-los passo a passo, mesmo que previamente conhecidos. Esta progressão encontra seu ápice divisório entre a reflexão do fazer externo e as intenções internas na segunda metade do século XIX em diante, como confirma Adorno:

\begin{abstract}
A técnica composicional enquanto reflexão sobre os meios, os quais em princípio eram distintos do fim, em origem sem dúvida o mesmo que o tratamento do parâmetro instrumental enquanto uma particular destreza artística derivada da reprodução, não se sedimentou até a segunda metade do século XIX como parte da composição. A tecnificação da obra de arte musical amadurece com a inclusão de técnicas que se haviam desenvolvido extraterritorialmente, no curso da evolução técnica global (ADORNO, 2006, p.235).
\end{abstract}

A tecnificação, neste contexto, significa mais que tecnologias, isto é, o avanço cada vez mais insurgente e imperante dos instrumentos musicais, por exemplo, ou das possibilidades de combinação, resolução ou agrupamento. Haveria, para Adorno, mais que uma influência cruzada. Adorno refere-se, por exemplo, a Berlioz como "protofenômeno da modernidade", especialmente no que tange à conjunção técnica composicional e atualização instrumental. E, ainda sobre o compositor francês, diz Adorno: "Ele criou a técnica composicional em sentido estri- 
to, como controle consciente de si mesmo de um extrato do material, o da realização instrumental, até então deixado para a intuição" (ADORNO, 2006, p.236).

Usando esse divisor de águas, diz que posteriormente a Berlioz, Liszt, Strauss, cuja separação entre técnica e composição tinha aparecido de maneira provocantemente inocente, houve um "progresso" em direção à primazia do que ele chama de "controle racional" da obra onde o extremo da racionalidade faz com que a técnica e o integral da obra sejam unidade. E faz, igualmente, com que essa unidade mostre a obra de modo que ao mesmo tempo ela seja e expresse.

Tecnificação da obra de arte igualmente se refere ao fato de que, mais e mais, a consciência da construção técnica tomou o todo da obra consciente. Isto inclusive vai-se dando, no tempo, através do que seja "ensinável" das técnicas composicionais. Ensinar, neste caso, significa conhecimento a posteriori, analitico, que se parametriza e, de alguma forma, condiciona o passar adiante a "tecnificação" da obra. Mário de Andrade se refere ao ensinável na arte em dois momentos. Num, o essencial, diz que "[...] a arte na realidade não se aprende. Existe, é certo, dentro da arte um elemento, o material, que é necessário por em ação, mover, pra que a obra de arte se faça [...] Afirmemos [...] que todo artista tem de ser ao mesmo tempo artesão" (ANDRADE, 1938, p. 11).

Num segundo momento mostra a ligação insubstituivel com o espírito:

[...] não temos que aprofundar [...] para reconhecer a necessidade imprescindivel de uma técnica pessoal [...] Mas essa técnica pessoal é inensinável, porém; cada qual terá que procurar e achar a sua, pra (sic) poder se expressar com legitimidade [...] A "técnica", no sentido em que a estou concebendo e me parece universal, é um fenômeno de relação entre o artista e a matéria que ele move. E si (sic) - espírito não tem limites na criação, a matéria o limita na criatura (Idem, p.25). 
Quanto à idéia de conteúdo espiritual, Adorno diz que essa noção que se projetasse para fora "com ajuda de uma técnica concebida de maneira não menos retificadora, é filistéia. $\bigcirc$ interior e o exterior geram-se reciprocamente" (ADORNO, 2006, p.234).

Assim, o conceito de "técnica pessoal", de Mário de Andrade, aflora no texto adorniano, quando este último também afirma que as técnicas "em seu sentido mais estrito prosperaram, na maior parte das vezes, junto com o procedimento composicional mesmo", isto é, através das práxis individuais. E, portanto, passiveis de serem ensinadas (Idem, p.235)

A ideia de ensinamento de técnicas de criação não invalida em absoluto a obra como resultado, mas faz um efeito importante que sempre é bom lembrar: influencia. De certo modo, considerando a importância da obra donde aquela técnica foi proveniente e foi posteriormente estudada, "inventa" tradição.

Mário de Andrade faz ver, nesse ponto, o quantum de divórcio que recentemente a música pode ter, na sua relação criação/recepção, devido ao que Adorno estaria chamando de controle racional da obra de maneira técnica como integralidade. Por primeiro, Mário de Andrade diz que é preciso distinguir técnica (que ele traduz por treino, prática) de conhecimento técnico, que segundo ele seria a vida intelectual da técnica. E continua:

A técnica em si nunca é demais, não está em condições de inflar abusivamente. Porque ela é só do artista em seu ofício e nunca do público. Não sendo do público (mesmo contando como público o próprio artista, depois de feita a sua obra-de-arte), ela não prejudica nem facilita o fenômeno da compreensão estética. Ela simplesmente não existe (ANDRADE, 1938, p.24).

Entretanto, o divórcio supramencionado faz do processo composicional contemporâneo sua força e individualidade, já que: 
[...] o artista que não seja ao mesmo tempo artesão, quero dizer, artista que não conheça perfeitamente os processos, as exigencias, os segredos do material que vai mover, não é que não possa ser artista (psicologicamente pode), mas não pode fazer obras de arte dignas deste nome. Artista que não seja bom artesão, não é que não possa ser artista: simplesmente, ele não é artista bom. E desde que vá se tornando verdadeiramente artista, é porque concomitantemente está se tornando artesão (Idem, p. 12). Pois, como diria Adorno, "de todas as maneiras a teoria não fica completamente invalidada frente à práxis: ela mesma surge na reflexão sobre suas experiências" (ADORNO, 2006, p.245).

A práxis, essa "reflexão sobre suas experiências", denuncia aquilo que se poderia chamar, no finalizar de uma obra, de técnica pessoal, a qual se não se reduz apenas a uma busca, mas principalmente uma incessante procura pela verdade interior do artista em realizar e como realizar a obra a um só tempo. Mário de Andrade se refere à técnica pessoal com muita ênfase, especialmente como "uma procura técnica de resolver o seu problema pessoal diante da obra de arte" (ANDRADE, 1938, p.24, grifos do autor).

\section{O Compositor contemporâneo}

Pode-se notar, advindo do pensamento desses dois grandes autores, que existe, de alguma forma, uma colocação metafísica para a realização da obra musical no que se refere à composição. Ou seja, a técnica, embora inegavelmente sempre existente e imprescindivel para a constituição da obra, é pertença, mas não aparência dela. A obra integral, por sua vez, inegavelmente existente, principalmente em seu conteúdo e significado, está eivada da técnica de construção dela, indissoluvelmente. Seria algo, mal comparando, como a alma e o corpo da composição.

Por outro lado, deduz-se que a técnica e a realização da 
obra - e então, como colocamos, o artesanato e a composição - são divisiveis do ponto de vista mais fundamental: o do ensino. Como já notaram e discutiram Adorno e Mário de Andrade, a parte ensinável da composição é efetivamente a técnica, ou as técnicas. Mas, como enunciou enfaticamente o compositor brasileiro Harry Crowl, numa mesa redonda de discussão sobre o métier composicional, "técnica é fundamental; agora, imaginação é indispensável" (III ENCONTRO NACIONAL, 2005, p.47).

Isto remete, na contemporaneidade, a uma situação cada vez mais insurgente na composição, qual seja, a técnica como finalidade expressiva. Desde os inícios do século XX, onde a revolução da "linguagem" musical se começa a fazer, como se sabe, a crescente busca da originalidade técnica construtiva da obra musical terminou por abarcar e envolver todo o processo de conteúdo expressivo da música contemporânea, caminho para a busca do novo, fazendo com que os próprios nichos técnicos as separassem. Durante as décadas de 1960 e 1970 houve um agravante extremo dessa situação, de forma que certa mentalidade de "vanguarda" pretendeu polarizar a ontologia musical, isto é, a pertinência das realizações composicionais que simplesmente não se enquadrassem nas sempre novas e experimentais visões técnicas de composição, como sendo, lembrando Wiora, o único e possivel caminho para a composição contemporânea. Entretanto, como qualquer movimento radical ou propenso à radicalização, após sedimentações e afirmações, tendeu a uma relativização; com isso, uma certa volta, digamos assim, à vigência da integralidade expressiva da obra se fez, convivendo mais ou menos pacificamente com todas as experiências e conquistas até então assertadas, a tradições havidas e "inventadas", retomadas e atualizadas. Porém isto se fez de maneira estamentária; assim, houve e continuou havendo aquela separação típica do pós-modernismo, em cujo seio o valor e a validade parecem se bastar apenas intrinsecamente, sem efetivamente se tocarem. A era dos estilos e influências aparentemente passou.

Tanto Adorno como Mário de Andrade se referem a esse fe- 
nômeno, um mais em favor do contexto contemporâneo, outro mais em favor da continuidade e transformação gradual da tradição.

Diz Adorno:

[...] a técnica musical e o conteúdo musical, totalmente imbricados, se devoram tal e qual os dois leoes na velha comédia. A técnica musical já não funciona como corretivo do assunto mas se converte em instância única. $O$ fetichismo no qual se movem os meios da cultura oficial musical continua triunfando entre seus inimigos vanguardistas (ADORNO, 2006, p.239).

E refere Mário de Andrade, sobre a contemporânea precedência da técnica sobre a integralização da obra:
A fixação dos conceitos nos levaria fatalmente a mera organização sistemática do nosso pensamento artístico, nos levaria a uma Estética, nos levaria a filósofos, sinão (sic) filosofantes e não aos artistas que devemos ser [...] o equilibrio ainda não se conseguiu [...] E é justamente essa atitude estética o que falta à grande maioria dos artis- tas contemporâneos: essa contemplação, essa serenidade oposta ao enceguecimento das paixöes e interesses (AN- DRADE, 1938, p.29-30).

Considerando, ainda, a indissociabilidade artesanato/obra, conteúdo/forma, conclui Mário de Andrade: "[...] puseram de lado essa importantissima parte do artesanato que deve haver na arte, que tem de haver nela para que ela se torne legitimamente arte" (Idem, p.30. Crifos do autor).

Claramente coloca-se aqui, então, a não subsunção de uma técnica, seja tradicional seja nova, a um objetivo artístico feito obra, seja em relação ou continuidade à tradição ou pretensiosamente inovadora. Ou seja, o "desenvolvimento e inflação do conhecimento técnico", como já referia Mário de Andrade (Idem, p.28), não devem obscurecer a "correção verificável na composição, elevada ao absoluto que se produz a custo de um conteúdo de verdade que não 
cabe buscar em lugar algum fora da obra", como referido por Adorno (ADORNO,2006, p.238).

O compositor contemporâneo, mormente o brasileiro, descortina pelo menos três espaços composicionais onde possa entrar e sair.

Poéticas que associem a composição acústica a diversas práticas tecnológicas. Derivadas diretamente das radicais rupturas das vanguardas, utilizam-se posmodernamente da evolução tecnológica direcionada a uma nova expressividade ou falta de expressividade como expressão. As técnicas são todas inscritas na inovação (novidade) entre linguagem e construção de linguagem. Poéticas cuja ligação música/tecnologia ocupa um segundo plano na criação ou, mesmo, sequer existe. São os efeitos do original enquanto transfiguração da ou de alguma tradição (os movimentos neo, as citações extensas, ocultas, inclusas, etc., o pseudorevisionismo e revisitações). As técnicas são todas adstritas ao continuísmo, a idéias reformuladas de coerência e lógica, maestrias.

Por fim, poéticas mistas, também chamadas ecléticas (com toda a problemática que vocábulo carrega) ou, no dizer de José Maria Neves, "de uma percepção pluri-sensorial da obra de arte" (NEVES, 1981, p.166) das quais um dos grandes exemplos é Almeida Prado. As técnicas são envolvidas pela "memória" das "tradições inventadas" e humor, sátira, paródia, teatro musical, motivações extramusicais em abundância, imagética abstrusa tanto quanto literária (mas não no senso do romantismo) e, por vezes usando o referencial da música de mercado da indústria cultural.

Afinal, o que se talvez possa depreender deste excurso que fizemos em torno da composição contemporânea é que, principalmente, ela instituiu para si própria sua instância criadora e autossustentável. fruivel desta vertente criadora não é exigente de espalhamento ou mobilidade social, mas pura e simplesmente de sobrevivência. Em grande parte criou e alimenta nichos para si em forma de departamen- 
tos universitários, festivais específicos, selos de gravação particulares (quando for o caso) ou, mais recentemente, o uso das tecnologias de informação de massa e redes sociais como espaços existenciais em si. É curioso observar como, até mesmo do ponto de vista muito humano das relações de aceitação social, essa composição demanda não mais que uns poucos ouvintes - mas um certo grupo, mais ou menos específico, de sabedores de sua existência e valor associado.

Já em 1958, Milton Babbitt observara que em vez de lamentarem o óbvio e irreparável rompimento entre a música de vanguarda e o público, os compositores, como os matemáticos, deveriam voltar as costas ao público e exigir seu lugar legítimo na academia. Caso contrário, a música deixaria de evoluir e, nesse importante sentido, de viver (in KERMAN, 1987, p. 135). Basicamente o que se ve aqui é a sobrevivência da composição enquanto composição, isto é, contemporaneamente na continuidade de seus processos técnicos e/ou técnico-expressivos de condução (mesmo que se possa objetar, em princípio, o termo evolução usado pelo eminente compositor americano, para ilustrar uma pretensa "morte da arte composicional" à Hegel/Fukuyama).

A relação composição e recepção da composição e sociedade é ampla e complexa demais para se discutir aqui. Por isso, a deixo para, quiçá, outra vez. Menciono apenas uma passagem, do Livro das Sonoridades, de Silvio Ferraz (2005, p. 127), talvez ilustrando o novo querendo ser novo, mas já sendo original e também por ser muito sugestiva:

"Entrevistando um candidato a compositor, perguntei-lhe sobre suas composições. Ele prontamente me apresentou uma série de peças, cada uma segundo um receituário teórico qualquer, mas todos muito importantes. Li as peças com atenção, mas algo me incomodava. Faltava alguma coisa ali? Teoricamente tuda estava correto, mas faltava algo. Perguntei então por que ele compunha música. que mais the atraía em música? Quais suas referencias, aquilo que ele mais gostava de ouvir, e assim por diante. Nada, nenhum compositor em especial, nenhuma música. 
Havia nele uma grande apatia quanto à música, mas um interesse enorme em ser aprovado como compositor".

\section{Referências}

ADORNO, Theodor W. Música y Técnica. In: Escritos Musicales I-III, Obra Completa n¹6. Madrid: Akal Ediciones, 2006.

ACAMBEN, Giorgio. Qu'est que c'est le contemporain? Paris: Rivages, 2008.

ANDRADE, Mário de. "O Artista e o Artesão". In: O Baile das Quatro Artes. São Paulo: Martins, 1938.

COELHO, Teixeira. Moderno pós moderno. Modos \& Versões. São Paulo: lluminuras, 2011.

III ENCONTRO NACIONAL DE COMPOSITORES UNIVERSITÁRIOS. Colóquios. Curitiva: Universidade Federal do Paraná, 2005.

FERRAZ, Silvio. Livro das Sonoridades (notas dispersas sobre composição. Rio de Janeiro: 7 Letras/FAPESP, 2005.

HOBSBAUM, Eric \& RANCER, Terence. A invenção das tradições. Rio de Janeiro: Paz e Terra, 1997. $2^{a}$ ed.

LEITE, Rogério Cezar de Cerqueira. Monteverdi, o Maquiavel da música. Folha de São Paulo. Suplemento MAIS!, 14 de março de 2004, p.3.

NASCIMENTO, João Paulo Costa. Abordagens do Pós Moderno em Música. A incredulidade nas metanarrativas e o saber musical contemporâneo. São Paulo: Cultura Acadêmica, 2011.

PONDÉ, Luis Felipe. Contra um mundo melhor. Ensaios do afeto. São 
Paulo: Leya, 2010.

POUND, Ezra. ABC da Literatura.Trad. Augusto de Campos e José Paulo Paes. São Paulo: Cultrix, 2006, $11^{10} \mathrm{ed}$.

SALLES, Paulo de Tarso. Aberturas e Impasses. O pósmodernismo na música e seus reflexos no Brasil, 1970- 1980. São Paulo: Ed. UNESP, 2005.

SCLIAR, Moacyr. O chato e o mediocre. Folha de São Paulo. Suplemento MAIS!, 13 de outubro de 2002, p. 10.

SHOSTAKOVITCH, Dmitri. The Power of Music. New York: MusicJournal, 1968.

WIORA, Walter. The four ages of music. Londres: Dent \& Sons, 1965. 